\title{
Hoe milieufactoren van belang kunnen zijn bij ontwerpen bedrijfsstrategie
}

\author{
Prof. Dr. S.W. Douma, Drs. J. de Groene en Prof. Dr. W.A. Hafkamp
}

\section{Inleiding}

Het milieu is zonder enige twijfel een uiterst belangrijk maatschappelijk en politiek onderwerp geworden. Maar in hoeverre moet een manager die betrokken is bij het ontwerpen van de strategie voor een bedrijf of business unit rekening houden met milieufactoren? En vooral: hoe moet hij dat doen? Dat zijn de twee vragen die, tegelijkertijd, in dit artikel aan de orde komen.

Om deze vragen te beantwoorden bekijken we de verschillende stappen in het traditionele proces van strategieformulering: vaststellen van de doelstellingen (paragraaf 2), omgevingsanalyse (paragraaf 3), sterkte/zwakte-analyse (paragraaf 4) en ten slotte formuleren van de strategie (paragraal 5).

\section{Vaststellen van de doelstellingen}

De eerste stap in het proces van strategieformulering is het vaststellen van de doelstellingen van de onderneming. Wij gebruiken daarbij het

Prof. Dr. S.W. Douma is hoogleraar Bedrijfseconomie, in het bijzonder organisatie van de onderneming, aan de Katholieke Universiteit Brabant.

Mw. Drs. J. de Groene studeerde Ruimtelijke Economie aan de Erasmus Universiteit Rotterdam. Sedert 1989 is zij werkzaam bij de vakgroep Bedrijfseconomie van de Katholieke Universiteit Brabant.

Prof. Dr. W.A. Hafkamp, ecometrist en milieu-econoom, is hoogleraar milieukunde aan de Erasmus Universiteit en bijzonder hoogleraar milieu- en natuurvraagstukken aan de Katholieke Universiteit Brabant. door Krijnen (1993) geformuleerde doelstellingenschema (zie fïguur 1). De belangrijkste doelstelling van de onderneming is volgens Krijnen het streven naar 'totale levensvatbaarheid'. Zoals blijkt uit figuur 1 valt de 'totale levensvatbaarheid' uiteen in de sociale levensvatbaarheid en de economische levensvatbaarheid. De sociale levensvatbaarheid wordt verder uitgewerkt tot maatschappelijke acceptatie en individuele acceptatie, terwijl de economische levensvatbaarheid gestalte krijgt in de vorm van financieel-economische doelstellingen en in het streven naar onafhankelijkheid en flexibiliteit.

Milieudoelstellingen vormen in dit schema een onderdeel van het streven naar maatschappelijke acceptatie en van het streven naar individuele acceptatie. Maatschappelijke acceptatie en individuele acceptatie zijn te zien als voorwaarden voor de levensvatbaarheid van de onderneming op lange termijn. Daarbij doet zich de vraag voor in hoeverre er een spanning bestaat tussen milieudoelstellingen enerzijds en financieel-economische doelstellingen anderzijds.

Wij gaan ervan uit dat financieel-economische doelstellingen bij het formuleren van de doelstellingen van de onderneming tenminste een zekere rol spelen. Dat betekent dat de ondernemingsleiding geïnteresseerd is in de rentabiliteit van de onderneming en mogelijk ook in groei van omzet, winst of winst per aandeel. Bijna alle ondernemingen hebben te maken met concurrentie van andere ondernemingen. Als er sprake is van een redelijk felle concurrentie, dan kunnen zij het zich eenvoudig niet permitteren om financieel-economische doelstellingen, zoals het streven naar een zo hoog mogelijke rentabiliteit, te verwaarlozen. Doen zij dat wel. dan verliest de onderneming op den duur de concurrentiestrijd en houdt zij op te bestaan. 


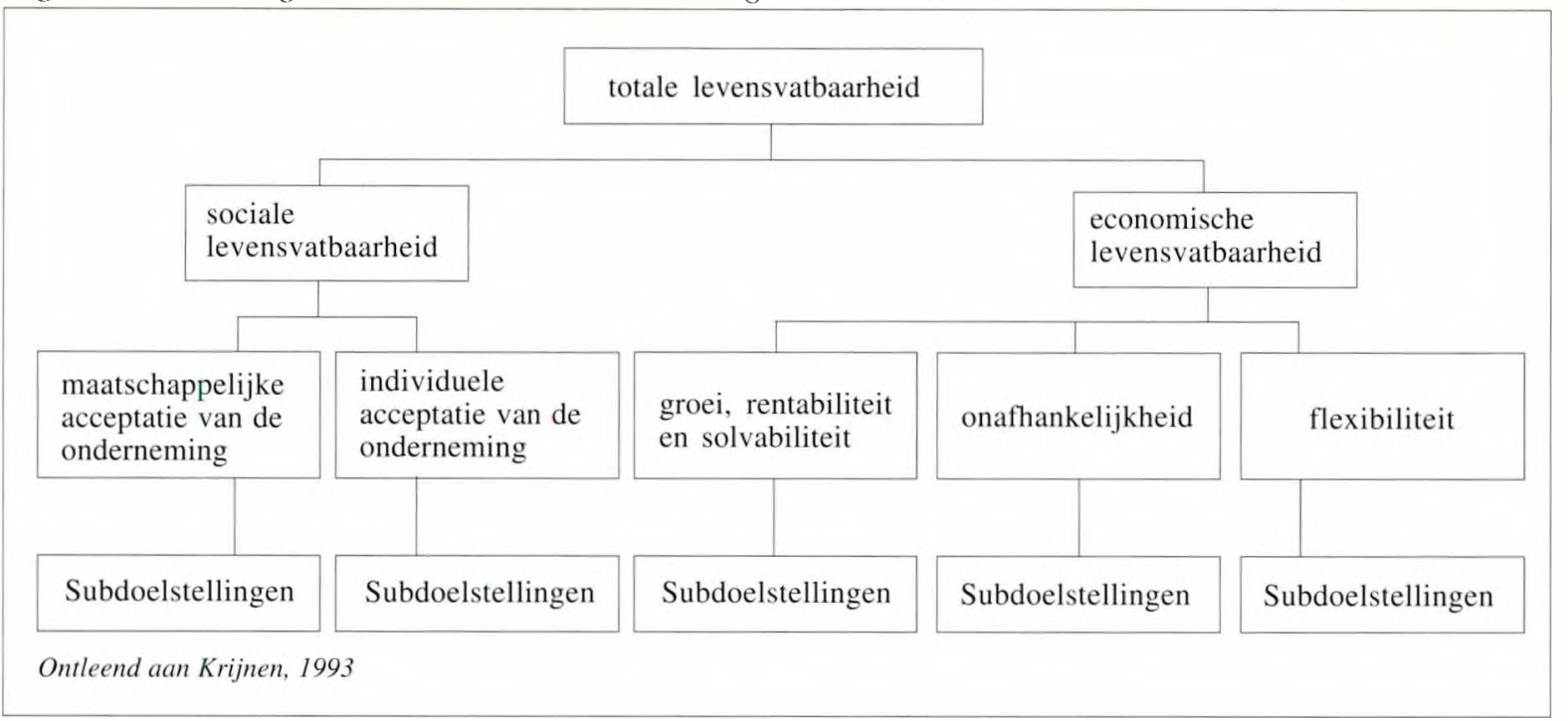

De vraag rijst dan of er nog wel ruimte is om naast financieel-economische doelstellingen nog andere doelstellingen, zoals milieudoelstellingen te hanteren. Het antwoord op die vraag hangt nauw samen met de vraag in hoeverre die twee soorten doelstellingen (milieudoelstellingen en financieel-economische doelstellingen) elkaar bijten. En juist op dit punt lopen de meningen uiteen.

Er zijn verschillende schrijvers die tot de conclusie komen dat het najagen van milieudoelstellingen de onderneming tevens economisch voordeel oplevert. Dat geldt bijvoorbeeld voor Kleiner (1990). Deze noemt verschillende ondernemingen die door het opzetten van milieuprojecten veel geld hebben bespaard. Eén daarvan is $3 \mathrm{M}$, die volgens Kleiner dankzij het 'Pollution Prevention Pays' programma sedert 1975500 miljoen dollar heeft bespaard, terwijl tevens allerlei emissies drastisch zijn gereduceerd. Daarnaast zegt Kleiner dat het ontwerpen van niet-verontreinigende produktieprocessen op den duur zal leiden tot lagere kosten. Daarbij gaat hij ervan uit dat emissies altijd berusten op fouten en dat het voorkomen van fouten altijd voordeliger is dan het achteraf herstellen van fouten. Die boodschap lijkt erg veel op de boodschap van de kwaliteitsgoeroe's die enkele jaren geleden furore maakten. Die gaan er ook van uit dat een gebrek in een eindprodukt altijd het gevolg is van een eerder gemaakte fout en dat het voorkomen van fouten altijd goedkoper is dan het achteraf herstel- len van fouten. Die redenering behoeft echter niet altijd op te gaan voor emissies. Sommige emissies zijn natuurlijk het gevolg van een fout. maar andere emissies horen eenvoudig bij het produktieproces (bij het opwekken van elektriciteit door middel van het verbranden van aardgas komt $\mathrm{H}_{2} \mathrm{O}$ en $\mathrm{CO}$, vrij; daar is nu eenmaal weinig aan te doen).

Het ligt daarom meer voor de hand om te veronderstellen dat het nemen van milieumaatregelen in de meeste gevallen leidt tot additionele uitgaven. Dat is ook precies wat Walley en Whitehead (1994) betogen in een artikel met de veelzeggende titel :'It's not easy being green'. Volgens deze auteurs is de tijd waarin het mogelijk was om grote verbeteringen op milieugebied te realiseren en daarbij ook nog financiële voordelen te behalen voorbij. De gemakkelijke projecten zijn al gerealiseerd. De kunst is nu volgens deze auteurs veel meer om een gegeven reductie van de verontreiniging te realiseren tegen zo laag mogelijke extra kosten. Voor die bedrijfstakken waarvoor de kosten van milieumaatregelen een belangrijk deel van de totale kosten zullen gaan vormen, wordt het concurrentievermogen van de onderneming voor een belangrijk deel bepaald door de efficiency van de genomen milieumaatregelen.

Het nemen van milieumaatregelen leidt dus in de meeste gevallen tot extra uitgaven op korte termijn. Het niet nemen van zulke maatregelen kan echter leiden tot omvangrijke financiële 
schade op een later tijdstip. Een goed voorbeeld daarvan wordt gevormd door de kosten van bodemsanering. De kosten van het saneren van de thans in gebruik zijnde industrieterreinen worden geraamd op 25 tot 50 miljard gulden. De huidige eigenaren worden tot sanering verplicht. Als deze eigenaren niet zelf de vervuiling hebben veroorzaakt. dan kunnen zij proberen de oorspronkelijke vervuilers voor de saneringskosten aansprakelijk te stellen. De bedragen die met bodemsanering zijn gemoeid kunnen zo hoog oplopen dat het voortbestaan van de onderneming erdoor in gevaar komt. Het grote probleem daarbij is dat het nu heel moeilijk is om te voorspellen voor welke soorten milieuschade de onderneming in de toekomst nog aansprakelijk zou kunnen worden gesteld (zouden ondernemingen twintig jaar geleden hebben voorzien dat zij voor de kosten van bodemsanering aansprakelijk zouden worden gesteld, dan zouden zij vermoedelijk toen meer preventieve maatregelen hebben genomen; voorkomen is waarschijnlijk per saldo voordeliger dan achteraf saneren). Dat betekent dat milieurisico's ook moeilijk verzekerbaar zijn. Wie de continuiiteit van de onderneming ziet als de centrale doelstelling van de onderneming, moet dus niet alleen kijken naar winstprognoses voor de komende een of twee jaar, maar ook naar financiële risico's als gevolg van toekomstige aansprakelijkheid voor milieuschade.

Er is echter meer. Het gaat immers niet alleen om financiële risico's. De reputatie van de onderneming staat op het spel. Zelfs als de financiële risico's van een milieuramp volledig door een verzekeririg zouden kunnen worden gedekt (quod non), dan nog kan een milieuramp de onderneming grote schade berokkenen. De onderneming die nalaat op tijd gepaste milieumaatregelen te nemen loopt het risico haar maatschappelijke acceptatie te verliezen. Daarbij is het goed te bedenken dat maatschappelijke normen ook veranderen. Wat vandaag nog maatschappelijk aanvaardbaar is, kan over vijf jaar als volstrekt ontoelaatbaar worden beschouwd. Als voorbeelden uit het verleden kunnen worden genoemd de toepassing van asbest en het gebruik van cadmium in kratten. Dat betekent dat de onderneming die zich niet aan die veranderende normen aanpast haar maatschappelijke acceptatie kan verliezen zonder dat er sprake is van een ramp in de zin van een ongeluk (zoals Bhopal en de Exxon Valdez). Dat kan leiden tot een uiterst stroeve relatie met lokale overheden, tot intrekking van vergunningen, tot grote ontevredenheid bij het eigen personeel en zelfs tot een kopersstaking.

Onze conclusie is dat er meerdere redenen zijn om bij het formuleren van de doelstellingen expliciet ook milieudoelstellingen op te nemen. Dat past heel goed in het in figuur I aangegeven doelstellingenschema van Krijnen. Het vormt een uitwerking van de doelstelling maatschappelijke acceptatie. Deze milieudoelstellingen zullen moeten worden geconcretiseerd door het vaststellen van concrete 'targets'. net zoals dat ook gebeurt bij het uitwerken van de financieeleconomische doelstellingen.

\section{Omgevingsanalyse}

Een tweede stap in het bepalen van de ondernemingsstrategie is het uitvoeren van een omgevingsanalyse. De omgeving van ondernemingen kan ingedeeld worden in de takkomgeving en in de algemene omgeving (Kast en Rosenzweig, 1979). De taakomgeving is dat deel van de omgeving waarmee de onderneming in directe interactie staat. De interactie met relevante stakeholders zoals afnemers, toeleveranciers, concurrenten, financiële instellingen en de overheid is een voorwaarde voor het bereiken van de doelstellingen. Met de algemene omgeving worden alle omstandigheden bedoeld die indirect van invloed zijn op de onderneming; de regels en vereisten waaraan een onderneming moet voldoen om steun en legitimatie te krijgen behoren daar ook toe. Relaties tussen een onderneming en andere ondernemingen spelen zich af tegen het decor van de algemene omgeving. Invloeden uit de algemene omgeving komen via actoren in de taakomgeving de onderneming binnen.

De algemene omgeving is de afgelopen jaren sterk veranderd door ontwikkelingen op milieugebied. Invloeden uit de algemene omgeving worden gewoonlijk bekeken naar verschillende dimensies of bereiken waarbinnen traditioneel een scala aan aspecten belicht wordt. Binnen elk van de dimensies is het echter mogelijk een aantal specifieke milieu aspecten te onderscheiden, waarvan we er bij wijze van voorbeeld steeds enkele noemen: 
Figuur 2: Milieufactoren in de omgevingsanalyse

\begin{tabular}{|lll|}
\hline $\begin{array}{l}\text { dimensie } \\
\text { econo- }\end{array}$ & traditioneel & milieu \\
misch & $\begin{array}{l}\text { inflatie } \\
\text { economische } \\
\text { groei }\end{array}$ & $\begin{array}{l}\text { prijsontwikkelingen van } \\
\text { water, energie en } \\
\text { overige natuurijke } \\
\text { hulpbronnen }\end{array}$ \\
techno- & $\begin{array}{l}\text { R\&D budgetten } \\
\text { logisch }\end{array}$ & $\begin{array}{l}\text { schone technologie: } \\
\text { versnelde veroudering }\end{array}$ \\
& $\begin{array}{l}\text { technologiën } \\
\text { sociaal }\end{array}$ & $\begin{array}{l}\text { milieubelastende } \\
\text { technieken }\end{array}$ \\
& $\begin{array}{l}\text { demografische } \\
\text { ontwikkeling } \\
\text { nieuwe lifestyles } \\
\text { sociale/bestuur- } \\
\text { lijke vernieuwing }\end{array}$ & $\begin{array}{l}\text { duturame ontwikkeling; } \\
\text { vergroening consument; } \\
\text { de mondige burger: }\end{array}$ \\
\hline
\end{tabular}

De vraag voor elke onderneming is om welke milieu-invloeden het precies gaat, hoe deze invloeden de onderneming raken, wat ze betekenen voor de huidige ondernemingsstrategie en welke de meest passende strategische respons is. Het is hierbij zaak om milieu-invloeden niet afzonderlijk te analyseren, maar als onderdeel van alle externe invloeden op de onderneming. De inwerking van die invloeden is ook niet rechtstreeks, maar werkt via de actoren in de taakomgeving.

Het is van belang om, voorafgaand aan een nadere analyse van de verschillende actoren in de taakomgeving, deze omgeving te typeren naar de kernbegrippen complexiteit en dynamiek. In nogal wat ondernemingen zorgt de factor milieu deze jaren voor een sterke dynamiek in de bedrijfsomgeving: dynamiek in de zin van snelle, plotselinge veranderingen (beter nog: als plotseling ervaren).

Te denken valt aan zaken als:

- de felle en plotselinge reactie van de consument bij milieu-incidenten met stoffen als PVC en dioxinen:

- de Duitse verpakkingswetgeving die vele exporterende bedrijven in Nederland verraste;

- de bodemproblematiek die vanaf midden jaren tachtig een tijdbom gelegd heeft onder duizenden bedrijven:

- de effecten van wetgeving en schaalvergroting in de afvalstoffenwereld (inzameling, bewerking en verwerking);

- de toenemende onaanvaardbaarheid van bestrijdingsmiddelen:
- de Europese regelgeving op milieugebied in het algemeen; deze komt soms langzaam op gang en verrast vervolgens de bedrijven in de lidstaten, zoals het geval was bij de richtlijn voor milieu-auditing.

Bij een sterke dynamiek in de bedrijfsomgeving is de onzekerheid over toekomstige ont wikkelingen vaak groot: komt die energieheffing er nu wel of niet? Dat vraagt om flexibiliteit en robuustheid in de ondernemingsstrategie. Dit geldt overigens ongeacht de vraag of het de factor milieu is die leidt tot sterke dynamiek of een andere factor.

Milieu kan soms, maar zelden alleen, bijdragen aan het bestaan van zeer complexe omstandigheden in de bedrijfsomgeving:

- verschillende overheden stellen stringenter, uiteenlopende, en soms tegenstrijdige milieueisen;

- bodemverontreiniging van een bedrijfsterrein kan leiden tot langdurig uitstel of afstel van bedrijfsverplaatsing of -uitbreiding;

- verschillende externe milieu-invloeden kunnen elkaar versterken. Dat vereist niet alleen een goede analyse, maar vooral ook een anticiperend ondernemingsbeleid.

In hun pogingen om de onzekerheid te reduceren hebben vele grote ondernemingen de laatste jaren milieu-managers aangesteld die niet alleen de complexiteit en dynamiek moeten analyseren, maar die ook de ondernemingsrespons vorm moeten geven; intern (milieuzorg, -auditing, -verslaglegging, produkt- en procesverbetering) en extern (overleg met overheden en milieu-organisaties, beleidsbeïnvloeding, lobbyen en samenwerking met andere schakels uit de keten).

Tot in de jaren tachtig was het in het algemeen alleen de overheid die in haar relatie tot bedrijven op milieugebied eisen stelde. Daar is sindsdien grondig verandering in gekomen (De Groene en Hafkamp, 1994). Tegenwoordig hebben zo ongeveer alle actoren in de bedrijfsomgeving verwachtingen, wensen en eisen die milieuaspecten van produkt en bedrijfsvoering omvatten. In de taakomgeving onderscheiden wij toetreders, substituten, toeleveranciers, concurrenten, afnemers, consumenten en de overheid. 
Naarmate ondernemingen in een bedrijfstak een hogere kapitials- en kennisintensiteit hebben wordt toetreding moeilijker. Dat geldt a fortiori waar deze twee veelal samenhangen met een tendens tot schalalvergroting. Voorbeelden hiervan zijn te vinden in de afvalbewerking (puinbrekers. gevaarlijk afval). In deze sector passen overheden bij het verlenen van vergunningen bovendien een 'doelmatigheidstoets' toe. De vergunning wordt uitsluitend verleend indien de aanvrager aannemelijk kan maken dat hij over aanvoer (van afvalstoffen) zal beschikken en dat de verwerking daarvan economisch haalbalar is.

\section{Substituten}

Nieuwe wetgeving en convenanten op het gebied van verpakkingen kunnen een grote bedreiging inhouden voor producenten van verpakikingsmaterialen (karton, glas), die substituut-materialen zien opkomen als belangrijke concurrenten. Naast deze beleidsrisico's kunnen de risico's ook in de consumentenmarkt liggen, zoals bijvoorbeeld het geval was bij de acties van milieu-organisaties tegen het gebruik van PVC als verpakkingsmateriaal. In enkele staten in de VS is de markt voor eenmalige luiers volledig verdwenen ten gunste van meermalige katoenen luiers, onder invloed van milieu-acties en plaatselijke wetgeving. Ook de combinatie van beleids- en marktrisico's kan dodelijk zijn.

\section{Toeleveranciers}

Toeleveranciers krijgen er meer en meer belang bij dat hun afnemers op een (milieu-) verantwoorde manier omgaan met hun materialen of produkten. Milieubeleid en -wetgeving stellen ook steeds vaker het principe van de producentenalansprakelijkheid centraal. Toeleveranciers kunnen zich bezighouden met de milieuzorg bij hun afnemers. In dat geval spreekt men van produkt-stewardship. De eisen van toeleveranciers kunnen naast milieuzorg ook technische (milieu-) voorzieningen betreffen en vormen van borg- of garantstelling. Deze kunnen een kostenverhogende werking hebben. Dit fenomeen ziet men vooral bij grote ondernemingen die relatief veel macht hebben op markten waar zij opereren (chemie, kunststoffen).

\section{Concurrenten}

Concurrenten in eenzelfde bedrijfstak dulden steeds minder de "dirty old man" in hun midden. Het Amerikaanse voorbeeld hiervan is het Responsible Care programma van de Chemical Manufacturers Association. Dit programma is verplicht voor alle leden van deze brancheorganisatie. In Nederland is het de Nederlandse Vereniging van Verwerkers van Chemische Afvalstoffen (de NVCA) die een milieu- en kwaliteitszorgsysteem heeft ontwikkeld dat verplicht is geworden voor alle angesloten leden.

\section{Afnemers}

Afnemers en toeleveranciers zijn in een aantal opzichten elkaars spiegelbeeld. Zo krijgen afnemers er belang bij dat hun toeleveranciers een milieusparende bedrijfsvoering hebben. Dat geldı vooral in situaties waarin (sub-)contractors. onderhoudsbedrijven en verzelfstandigde bedrijlsonderdelen in een vrij sterke symbiose leven met hun opdrachtgever. Het geldt ook sterker naarmate de buitenwereld niet bereid of in staat is om het onderscheid te maken tussen een afnemer (chemiereus, automobielfabrikant) en diens toeleveranciers (rederij, componenten). In dit verband wordt wel de term environmental comakership gebruikt.

De milieu-eisen van afnemers kunnen belangrijk zijn in het begin van de bedrijfskolommen (zoals in de chemie, aardolie), middenin (elektronica, automobiel), dichter bij de consument (groothandel. detailhandelsketens), of helemaal achteraan (in de afvalverwerking). Bij een bedrijf als DMV International in Veghel is het vooral cle zware betrokkenheid geweest van afnemers in de pharmaceutische industrie (in Europa, Japan, en de VS) die aanleiding is geweest voor een intensivering van de milieuzorg.

\section{Consumenten}

De consument, de ultieme afnemer, doet steeds meer kennis op over de milieu-aspecten van produkten en van de eigen consumptie. Hij laat milieuargumenten meewegen in zijn aankoopbeslissingen. en blijkt - binnen zekere grenzen - bereid te zijn meer te betalen voor produkten die minder milieubelastend zijn. Hij is ook bereid meer moeite te doen, bijvoorbeeld door mee te werken aan retoursystemen en gescheiden inzameling van afval. 


\section{De overheid}

Bij een analyse van de invloed van milieufactoren moet de rol van de overheid een belangrijke plaats innemen. Hierboven is al gesproken van beleidsrisico's. In de toekomst is het te verwachten dat de overheid een rol van belang blijft spelen op milieugebied. Dat zal op zeer uiteenlopende manier merkbaar worden in verschillende bedrijfstakken. De overheid werkt momenteel simultaan op verschillende sporen:

- intensivering vergunningverlening, verscherping van handhaving;

- frequenter inzet strafrecht;

- aansprakelijk stellen van bedrijven voor milieuschade (bodem);

- de inzet van financiële instrumenten voor milieubeleid;

- de ontwikkelingen van nieuwe, interactieve stijlen van beleidsontwikkeling.

De overheid is zich er meer dan vroeger van bewust dat ze opereert in de taakomgeving van en in mindere mate in de algemene omgeving van ondernemingen en speelt daar nadrukkelijk op in.

De conclusie van deze paragraaf is dat milieuinvloeden zich manifesteren zowel in de algemene als in de taakomgeving van ondernemingen. De actoren in de taakomgeving kunnen een behoorlijke druk op de onderneming uitoefenen en ondernemingen ertoe dwingen expliciet een overeenkomstig milieubeleid te voeren.

\section{Sterkte/zwakte-analyse}

De derde stap in het proces van strategieformulering is het uitvoeren van een sterkte-zwakte analyse. Het predikaat sterk of zwak wordt in relatie tot het verleden of de toekomst van de onderneming gegeven of in relatie tot een andere onderneming in dezelfde bedrijfstak.

Voor een bespreking van de sterkten en zwakten met betrekking tot milieuzorg en -beleid kan een aanknopingspunt gevonden worden in de tussenevaluatie van de ontwikkeling van bedrijfsinterne milieuzorgsystemen (Van Someren e.a., 1993). In deze tussenevaluatie is door middel van een representatieve steekproef uit het bestand ondernemingen dat wordt geacht in 1995 een bedrijfsintern milieuzorgsysteem te hebben, informatie verkregen over tal van zaken met betrekking tot milieuzorg in die ondernemingen. Daarbij zijn ook de belemmerende en bevorderende factoren aan de orde gekomen.

Als belemmerende factoren zijn genoemd:

- tijds- en capaciteitsproblemen;

- schaarste aan financiële middelen;

- gebrek aan kennis;

- onzekerheid met betrekking tot overheidseisen;

- interne organisatieproblemen.

Bevorderende factoren voor milieuzorg zijn:

- overheidseisen;

- bedrijfseconomische overwegingen op lange termijn;

- synergie met andere zorgsystemen;

- persoonlijke overtuiging sleutelfunctionarissen;

- imago.

Een aantal van deze belemmerende en bevorderende factoren is terug te vinden in de in de strategie-literatuur genoemde strategische kenmerken. Strategische kenmerken die (kunnen) samenhangen met milieuzorg zijn: produktpositionering, reputatie en naamsbekendheid, technologische know-how, ervaring, marketing know-how en organisatorische en 'managerial' know-how (Douma, 1993).

Uit deze opsomming en de hierboven genoemde belemmerende en bevorderende factoren destilleren wij drie aspecten aan de hand waarvan de sterkten en zwakten van ondernemingen met betrekking tot milieuzorg nader bekeken worden (zie ook Van Goor, 1994). De drie aspecten zijn:

- organisatie: hieronder vallen alle zaken met betrekking tot de opbouw, structurering, vormgeving en functioneren van een onderneming;

- techniek: met dit aspect wordt de technische vormgeving van met name het produktieproces bedoeld, maar ook de gebruikte techniek in andere afdelingen. Tevens is de wijze waarop in een organisatie ingespeeld wordt of vooropgelopen op technologische ontwikkelingen van belang;

- mensen: de wijze waarop mensen in een organisatie (samen)werken en de kwaliteit van mensen in termen van kennis, ervaring en vermogen om te leren, zijn bij dit aspect van belang.

Het samenspel van deze drie aspecten beïnvloedt het functioneren en de effectiviteit van een 
onderneming. Het manifesteert zich in de gehele organisatie, op alle niveaus en in alle afdelingen. Vanuit milieu-oogpunt zijn de volgende 'afdelingen' in een onderneming van belang: de topleiding, de $R \& D$ afdeling, de produktieafdeling en de verkoop- en marketingafdeling. Als nu de aspecten organisatie, techniek en mensen op milieugebied per afdeling nader beschouwd worden, ontstaat de volgende matrix:

Figuur 3: Mogelijke sterke en zwakke punten op milieugebied

\begin{tabular}{|c|c|c|c|}
\hline $\begin{array}{l}\text { aspect } \\
\text { afdeling }\end{array}$ & organisatie & techniek & mensen \\
\hline topleiding & $\begin{array}{l}\text { - formuleren milieubeleidsver- } \\
\text { klaring } \\
\text { - opstellen en implementeren } \\
\text { milieuzorgsysteem } \\
\text { - synergie met zorgsystemen } \\
\text { - informatie m.b.t. ontwikke- } \\
\text { lingen in omgeving } \\
\text { - informatie m.b.t. overheids- } \\
\text { regulering } \\
\text { - toedeling taken, verantwoor- } \\
\text { delijkheden en bevoegdheden } \\
\text { op milieugebied } \\
\text { - toewijzing financiële } \\
\text { middelen op milieugebied }\end{array}$ & $\begin{array}{l}\text { - aandacht voor technische } \\
\text { ontwikkelingen (proces- } \\
\text { geïntegreerd, end-of-pipe) } \\
\text { - allocatie middelen voor } \\
\text { milieuvriendelijke technieken }\end{array}$ & $\begin{array}{l}\text { - persoonlijke overtuiging } \\
\text { - motivering medewerkers } \\
\text { - kennis en expertise op milieuge- } \\
\text { bied, en ontwikkelen daarvan }\end{array}$ \\
\hline$R \& D$ & $\begin{array}{l}\text { - taken, verantwoordelijkheden } \\
\text { en bevoegdheden op milieu- } \\
\text { gebied } \\
\text { - financiële middelen om } \\
\text { aandacht aan milieuzaken te } \\
\text { besteden }\end{array}$ & $\begin{array}{l}\text { - aandacht voor milieu-aspecten } \\
\text { in proces- en produktontwik- } \\
\text { keling in het algemeen } \\
\text { - ontwikkeling milieuvriende- } \\
\text { lijke processen en produkten } \\
\text { - adequate outillage } \\
\text { - ontwerp meet- en registratie- } \\
\text { systeem }\end{array}$ & $\begin{array}{l}\text { - specialisten op milieugebied } \\
\text { - aanvullende kennis op } \\
\text { milieugebied } \\
\text { - voeling voor milieuzaken }\end{array}$ \\
\hline produktie & $\begin{array}{l}\text { - taken, verantwoordelijkheden } \\
\text { en bevoegdheden op milieu- } \\
\text { gebied } \\
\text { - milieuzorgsysteem }\end{array}$ & $\begin{array}{l}\text { - procesgeïntegreerde } \\
\text { installaties } \\
\text { - end-of-pipe technieken } \\
\text { - meet- en registratiesystemen } \\
\text { - gescheiden afvalinzameling }\end{array}$ & $\begin{array}{l}\text { - good house keeping } \\
\text { - afvalbewaking } \\
\text { - ideeëngeneratie }\end{array}$ \\
\hline $\begin{array}{l}\text { verkoop en } \\
\text { marketing }\end{array}$ & $\begin{array}{l}\text { - taken, verantwoordelijkheden } \\
\text { en bevoegdheden op milieu- } \\
\text { gebied } \\
\text { - analyse van markt, } \\
\text { green consumers } \\
\text { - product stewardship } \\
\text { - vertaling wensen markt naar } \\
\text { R\&D en produktie }\end{array}$ & $\begin{array}{l}\text { - milieukeur } \\
\text { - recycling } \\
\text { - reversed Iogistics }\end{array}$ & $\begin{array}{l}\text { - kennis en voeling markt m.b.t. } \\
\text { milieuvriendelijke produkten } \\
\text { - beïnvloeden markt m.b.t. } \\
\text { aankoop milieuvriendelijke } \\
\text { produkten } \\
\text { - concurrentie op milieuwaarden }\end{array}$ \\
\hline
\end{tabular}


In de tabel is te zien dat bij het aspect organisatie de juiste toekenning van taken, verantwoordelijkheden en bevoegdheden een belangrijke factor is. De topleiding kan dit op milieugebied doen door deze te omschrijven in het milieuzorgsysteem. Als op de afdelingen en bij de medewerkers bekend is wat ieder moet, mag en kan doen, krijgt milieuzorg structureel aandacht. Uiteraard dienen de taken, verantwoordelijkheden en bevoegdheden op milieugebied geïntegreerd te zijn met die op andere terreinen. De topleiding heeft daarnaast de taak om ontwikkelingen in de omgeving, dus ook op het terrein van de overheidsregulering te scannen. Het niet of te laat op de hoogte zijn kan ongewenste gevolgen hebben voor de onderneming, bijvoorbeeld door het achterlopen op de concurrenten, of het plotseling geconfronteerd worden met dwangsommen, intrekken van vergunning of zelfs strafrechtelijke vervolging.

Als laatste is ook het alloceren van financiële middelen voor milieuzorg een belangrijk punt; het alleen met de mond belijden of organisatorisch vormgeven is niet genoeg.

Op het gebied van de techniek is naast het daadwerkelijk investeren in milieuvriendelijke technieken, ook het onderzoek en de aandacht daarvoor van belang. De verkoop- en marketingafdeling kan ingeschakeld worden bij het opzetten van een systeem voor het terughalen van produkten en verpakkingsmaterialen bij de afnemers (reversed logistics); daarnaast kan de milieukeur gebruikt worden als een techniek om de milieuvriendelijkheid van produkten tot uiting te brengen.

De mensen in een organisatie, de topleiding zowel als de medewerkers, kunnen door hun kennis en inzet in belangrijke mate bijdragen aan het succes van een milieubeleid van de onderneming. De topleiding heeft hierin een speciale taak; uit diverse onderzoeken is gebleken dat de houding van de top op milieugebied een noodzakelijke voorwaarde is voor het motiveren van medewerkers (o.a. Van Someren 1993, Cramer en Roes, 1992).

Technische kennis, organisatietalent en creativiteit zijn dus belangrijke sterke punten op het gebied van milieuzorg voor een onderneming. Een slechte organisatorische vormgeving van milieuzorg, niet of te weinig adequate technieken en onvoldoende gemotiveerde mensen maken een ondernemer kwetsbaar. Deze kwetsbaarheid kan tot grote financiële schade leiden (bodemsanering, dwangsommen etc.), maar ook de reputatie en het imago van ondernemingen aantasten.

Ondernemingen moeten hun sterke punten uitbuiten en met name die sterke punten die schaars en moeilijk verhandelbaar zijn. Op milieugebied kan dit een nieuwe procestechnologie zijn of de ontwikkeling van een milieuvriendelijker produkt. Maar ook een activum als gemotiveerd en betrokken personeel is van onschatbare waarde voor een onderneming.

\section{Het formuleren van de strategie}

Nadat de omgevingsanalyse is uitgevoerd en de sterke en zwakke punten van de onderneming zijn geïnventariseerd, moet de strategie worden geformuleerd. Daarbij zal de onderneming proberen een verdedigbaar concurrentieel voordeel te verkrijgen. Om daarin te slagen moet de onderneming iets doen wat moeilijk door andere ondernemingen kan worden nagevolgd. Daarbij moet de onderneming vier met elkaar samenhangende keuzes maken:

- ze moet kiezen voor een strategie van de laagste kosten of voor een strategie van produktdifferentiatie;

- ze moet een bepaalde segmentenscope kiezen;

- ze moet beslissen wanneer ze bepaalde acties onderneemt;

- ze moet nagaan of ze door samenwerking met andere business units van hetzelfde concern haar concurrentievermogen kan versterken.

Deze vier keuzes zijn in beeld gebracht in figuur 4 (zie pag. 186).

\section{Laagste kosten of produktdifferentiatie}

Ondernemingen moeten dus in de eerste plaats een keuze maken tussen een strategie van de laagste kosten en een strategie van produktdifferentiatie. Een keuze voor een strategie van de laagste kosten houdt in dat de onderneming probeert produkten die zich niet duidelijk onderscheiden van de produkten van concurrenten tegen zo laag mogelijke kosten te produceren. Een strategie van produktdifferentiatie houdt in dat de onderneming probeert haar produkten te onderscheiden van de produkten van haar concurrenten op een zodanige wijze dat (sommige) afnemers bereid zijn voor deze produkten een hogere prijs te betalen. 


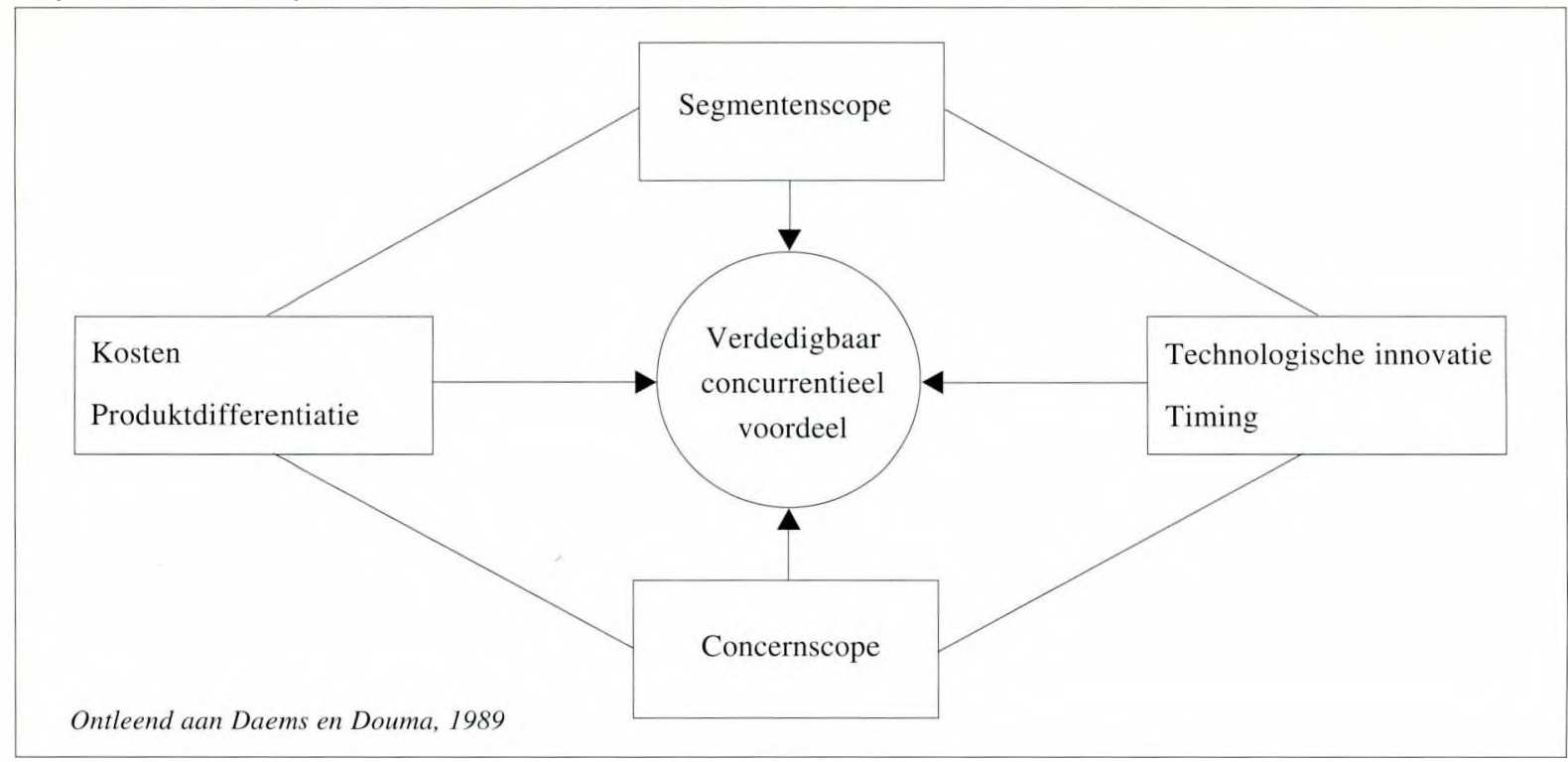

In hoeverre zijn milieufactoren nu van invloed op de keuze tussen een strategie van de laagste kosten of een strategie van produktdifferentiatie?

De onderneming die heeft gekozen voor een strategie van de laagste kosten moet zich goed realiseren dat het rekening houden met milieufactoren in het algemeen leidt tot een kostenverhoging. Indien alle ondernemingen waarmee de onderneming concurreert dit tegelijkertijd en in dezelfde mate doen heeft dat geen invloed op het concurrentievermogen van de onderneming. Maar als de onderneming veel eerder dan andere ondernemingen overgaat tot het nemen van kostenverhogende maatregelen, verslechtert haar concurrentiepositie wel. Vooral als de onderneming wordt geconfronteerd met concurrentic uit landen waar het milieu nog niet een even hoge maatschappelijke prioriteit heeft (zoals thans nog het geval is in de landen voortgekomen uit de vroegere SovjetUnie), kan haar relatieve kostenpositie sterk verslechteren. Dat maakt een strategie van de laagste kosten moeilijker.

Er is echter ook een andere mogelijkheid. Stel dat de onderneming erin slaagt een nieuwe technologie te ontwikkelen waarmee tegen bescheiden meerkosten aan veel strengere milieu-eisen kan worden voldaan. De invoering van strengere regelgeving leidt dan voor de onderneming tot een kostenvoordeel zolang concurrenten niet over die nieuwe technologie kunnen beschikken.

In bedrijven met 'natte processen' zoals in de levensmiddelen- en textielindustrie, leidt een concentratie van hergebruik (van spoelwater) en regeneratie (van grondstoffen) tot besparingen op water, grondstoffen en milieuheffingen (WVO). De kosten van de betreffende grondstoffen en water zijn weliswaar laag in relatie tot andere kostencategorieën, maar de besparingen erop zijn significant in relatie tot de netto-marge op de produkten. Zie verder de analyses van Boons (1993) en Boons en Neumann (1993) voor respectievelijk Ossfloor en Akzo fibers.

De onderneming die kiest voor een strategie van produktdifferentiatie zal zich realiseren dat er door rekening te houden met milieufactoren een differentiatiemogelijkheid bij komt. De onderneming kan haar produkten nu uitdrukkelijk milieuvriendelijker maken dan de produkten van concurrenten. Daarbij moet worden gedacht aan de gebruikte grondstoffen, aan de inrichting van het produktieproces, aan de milieufactoren verbonden aan het gebruik van het produkt en aan de mogelijkheden tot terugwinning van de gebruikte grondstoffen.

Verfproducenten bieden een steeds breder 'palet' aan verven en lakken waarin milieusparende varianten een belangrijke plaats innemen.

\section{De segmentenscope}

De tweede keuze heeft betrekking op de segmentenscope. Daarmee wordt bedoeld de keuze van de marktsegmenten die de onderneming wil bedienen en in het verlengde daarvan de keuze van de produkten die daarbij horen en de keuze van de 
technologieën die de onderneming wil gebruiken.

Om daarvan een voorbeeld te geven: een fabrikant van bestrijdingsmiddelen kan wat betreft marktsegmenten kiezen tussen de segmenten van de boeren en tuinders, gemeentelijke en andere plantsoenendiensten en bezitters van particuliere tuinen. Doordat het milieu nu voor veel gebruikers van bestrijdingsmiddelen een belangrijk aandachtspunt is geworden ontstat er een extra mogelijkheid tot segmentatie: in ieder van deze drie marktsegmenten kunnen zich in principe meer en minder milieubewuste gebruikers bevinden. Daardoor ontstaan niet drie maar zes marktsegmenten. De onderneming moet nu kiezen of ze zich tot die nieuwe marktsegmenten (de milieubewuste gebruikers van bestrijdingsmiddelen) wil wenden met afzonderlijk voor die groep ontwikkelde nieuwe produkten of dat zij alle marktsegmenten wil blijven bedienen met in principe dezelfde produkten (die dan minder schadelijk voor het milieu moeten worden). In de wasmiddelenmarkt is er lange tijd een marktsegment geweest voor fosfaatarme wasmiddelen (zeepfabriek De Klok). Overigens kunnen er diepgaande verschillen van mening bestaan over de milieuvriendelijkheid van bepaalde produkten.

In verschillende Europese landen zijn de laatste 12 jaar diepgaande vergelijkende analyses uitgevoerd naar de milieubelasting door eenmalige kartonnen melkverpakkingen versus meermalig glas. Onlangs is dat in Nederland nog gedaan door TNO in het kader van de milieu-analyses van het Verpakkingenconvenant. Ook daarbij is niet geconcludeerd dat een meermalige verpakking (glazen fles of polycarbonaat), tot een substantiële reductie van milieu-effecten leidt.

\section{Timing}

Door als eerste een nieuw milieuvriendelijk produkt te introduceren kan de onderneming een belangrijk concurrentieel voordeel verwerven.

Vrachtwagenfabrikant DAF kwam als eerste met de introductie van een nieuwe, geluidsarme en schone dieselmotor voor zware vrachtwagens. Producenten van consumentenelektronica werken momenteel aan milieusparende ontwerpen van produkten als tv's, wasmachines en koffiezetters. Ze doen dit om tijdig in te kunnen spelen op de aanstaande terugnameverplichting (Criens en Sondern, 1994).

Anderzijds kan de onderneming met een kostennadeel worden geconfronteerd door maatregelen te nemen gericht op minder milieubelastende produktieprocessen. Timing van dergelijke maatregelen is een delicat onderwerp, waarbij de onderneming moet laveren tussen de Scylla van maatschappelijke acceptatie en mogelijke toekomstige schadeclaims enerzijds en de Charibdis van verlies van marktaandeel door hogere kosten anderzijds.

\section{Samenwerking met andere business units van hetzelfde concern}

De onderneming zal ten slotte goed moeten nagaan of ze gebruik kan maken van bij zusterondernemingen reeds opgebouwde kennis en ervaring. Die kennis en ervaring kan betrekking hebben op technologische kennis, juridische kennis met betrekking tot voorschriften en vergunningen, het omgaan met actiegroepen en lokale overheden en public relations. Dit betekent dat nieuwe technologieën die in bepaalde bedrijfstakken ontwikkeld zijn, in een andere bedrijfstak gecombineerd kunnen worden tot nieuwe, milieusparende processen.

Zo maakt de toepassing computers en laserapparatuur in de grafische sector (drukkerijen), dat minder afval ontstaat, minder verontreinigd water geloosd wordt, er minder luchtverontreiniging optreedt, terwijl het drukwerk een hogere kwaliteit krijgt bij lagere kosten.

\section{Besluit}

De vraag of een manager bij het ontwerpen van de strategie voor een bedrijf of een business unit rekening moet houden met milieufactoren kan bevestigend beantwoord worden. In dit artikel is getracht aan te geven dat er meerdere redenen zijn om bij het formuleren van de strategie milieudoelstellingen op te nemen. Het expliciet betrekken van milieufactoren is onontkoombaar als de onderneming ook maatschappelijk aanvaardbaar wil functioneren. Uit de bespreking van de omgeving van cle onderneming is gebleken dat milieuinvloeden zich manifesteren in de taakomgeving en in de algemene omgeving van de onderneming. Actoren in de taakomgeving kunnen een behoorlijke druk uitoefenen op de onderneming. Athankelijk van de sterke en zwakke punten van de onderneming op het gebied van technische kennis, organisatietalent en creativiteit. zal de onderne- 
ming trachten op de omgeving in te spelen.

Daarbij moeten keuzes gemaakt worden op het gebied van laagste kosten of produktdifferentiatie, de segmentenscope, de timing en eventuele samenwerking.

Hoe een manager bij het ontwerpen van een strategie rekening moet houden met milieufactoren is afhankelijk van de omgeving en de sterke en zwakke punten van de onderneming. In dit artikel is besproken hoe die omgeving geanalyseerd kan worden en welke sterke en zwakke punten van belang (kunnen) zijn bij het integreren van milieufactoren in de besluitvorming. Uiteindelijk zullen deze analyses leiden tot de keuze van een bepaalde strategie waarin de milieucomponent duidelijk aanwezig zal zijn.

\section{I T E R A T U U R}

Boons, F., (1993), Precari, Bedrijfsrapportage Ossfloor b.v. (Oss), Erasmus Studiecentrum voor Milieukunde, EUR, Rotterdam.

Boons, F. en F. Neumann, (1993), Precari, Bedrijfsrapportage AKZO Fibers b.v. FSI (Arnhem), Erasmus Studiecentrum voor Milieukunde, EUR, Rotterdam.

Cramer, J. en B. Roes, (1992), Betrokkenheid van werknemers bii milieuzorg, COB/SER, Den Haag.

Criens, R.M., (1994), Recycling of Household Appliances, in: Wim Bogersstichting (red.), Een duurzame bedriffskolom? Milieugericht Integraal Ketenbeheer, Congresbundel,
Katholieke Universiteit Brabant, Tilburg, pp. 78-85.

Daems, $\mathrm{H}$ en S. Douma, (1989), Concurrentiestrategie en concernstrategie, Kluwer, Deventer.

Douma, S., (1993), Analyse van de sterke en zwakke punten van de onderneming, in: S. Douma, Ondernemingsstrategie, Kluwer, Deventer.

Goor, J. van, (1994), Schone kansen, op zoek naar open deuren, in: E.W.L. van Engelen en J. van Goor (red.), Schone kansen; denkbeelden over ondernemerschap en milieumanagement, Stichting Toekomstbeeld der techniek, Samsom BedrijfsInformatie, Alphen aan den Rijn/Zaventem.

Groene, A. de en W. Hafkamp, (1994), Milieu als een nieuwe factor in de bedrijfsvoering, in: F. Dietz, W. Hafkamp en J. van der Straaten (red), Basisboek Milieu-economie, Boom, Meppel.

Kast, F. en J. Rosenzweig, (1979), Organization and Management, a systems and contingency approach, McGraw-Hill.

Kleiner, A., (1991), What does it mean to be green?, Harvard Business Review, Volume 69, no. 4 July-August, pp. 38-47.

Krijnen, H.G., (1993), De doelstellingen van de onderneming, in: S. Douma, Ondernemingsstrategie, Kluwer, Deventer.

Someren T.C.R. van e.a., (1993), Onderzoeksrapport Bedriffsmilieuzorgsystemen, Tussenevaluatie 1992, KPMG Milieu, IVA, Den Haag, Tilburg.

Sondern, A.D., (1994), The Philips TV and the environment, in: Wim Bogersstichting (red.), Een duurzame bedriffskolom? Milieugericht Integraal Ketenbeheer, Congresbundel, Katholieke Universiteit Brabant, Tilburg, pp. 72-77.

Walley, N. en B. Whitehead, (1994), It's not easy being green, Harvard Business Review, Volume 72, no. 3, May-June, pp. 46-52. 